\title{
Implementation of Open Selection Policy in the Position of Pratama High Leaders in Pekanbaru City, Riau Province
}

A. Mius (Correspondence Author)

Pekanbaru City's Employee

Ermaya Suradinata

Pekanbaru City’s Employee

Muh. Ilham,

Pekanbaru City's Employee

H. M. Aries Djaenuri

Pekanbaru City's Employee

Received: April 3, 2019 Accepted: May 10, 2019 Online published: May 21, 2019

doi:10.5296/jpag.v9i2.14605 URL: https://doi.org/10.5296/jpag.v9i2.14605

\begin{abstract}
Open Selection Policy in First-Top Manager is the implementation of Law Number 5 Year 2014 about State Civil Apparatus (SCA). Open selection purpose to create apparatus who has the professional and based on a merit system. Open Selection Policy Implementation in Pekanbaru City is the first policy implemented in Sumatera Island. This research is using a descriptive design with a qualitative approach. Research informants are gathering from the assessor, local head, head of the selection team, SCA whoever joint the selection and SCA who has passed the selection. Data analyzing technique is using the descriptive technique with the interview, observation, and documentation as the data collecting technique. Research result shows that Implementation of Open Selection Policy for the First-Top manager in Pekanbaru City is done with the effectivity of communication and clear-share authority for each organ who implementing the policy. Besides that, there are big funds for building
\end{abstract}


assessment center, the suitability of workload and program incentives, and there is an indication for time uncertainty in each selection phase. The ideal model for open selection policy in Pekanbaru City is theoretical enrichment from Edwards III's theory of Policy Implementation with adding environment variable and transparency indicator in communication variable.

Keywords: policy implementation, open selection, human resources management, merit system

\section{Introduction}

One of the government's efforts in bureaucratic reform policy is to revise legislation related to staffing. Law No. 43 of 1999 concerning the Principles of Staffing which has been running for almost 20 years has undergone a revision with the issuance of Law Number 5 Year 2014 concerning the State Civil Apparatus (ASN). One aspect that has changed with the enactment of Law No. 5 of 2014 is the filling of echelon II and echelon I officials and heads of non-ministerial government institutions as termed in the new regulation is the High Leadership Position (JPT). Before the enactment of Law No. 5 of 2014, the filling of echelon II positions within the regional government is carried out by the appointment of regional heads.

In fact, before the ASN Law came into effect with the appointment of a structural position based on the authority of the regional head, various problems arose. Setiawan (2016) in his research asserted that the relationship between regional heads and structural officials in the regions who are patron-client can result in damage to governance and inhibit the realization of a healthy bureaucracy. This brings up various work programs that are the responsibility of the regional apparatus organization led by these officials will not run well. While Sepriyanto (2013) concludes the same conclusion that "the appointment of structural officials in the region has been based largely on the likes and dislike of regional heads". But at present, the appointment of structural officials is done professionally with an open selection method or commonly known as position auction.

Actually, the term auction position refers to the method of appointment or filling in structural positions in the government, both central and regional through an open promotion system. Position auctions are believed to be the biggest levers of bureaucratic change. In addition to fostering healthy, fair, objective competition, also free from $\mathrm{KKN}$, open promotions through job auctions are conducted transparently, using certain indicators and carried out by neutral and competent parties to make selections. At present, this model is believed to be the most appropriate means to get the best leadership candidates or officials. With the ASN Law, the government stipulates that the process of recruiting public positions is carried out through the Merit System, namely, recruitment based on qualifications, competencies, and performance fairly and fairly regardless of political background, race, color, religion, origin, gender, marital status, age, or disability condition. Indeed, the ASN Law is a milestone in improving ASN career management which is carried out fairly and fairly.

The open selection in the State Civil Apparatus Act is regulated in article 72 that "every civil 
servant who fulfills the requirements has the same rights to be promoted to a higher level of office." This means that the career system and promotion of Civil Servants must be open and competitive. To follow up on the ASN Law, Government Regulation Number 11 of 2017 concerning the Management of Civil Servants is issued. The High Leadership Position (JPT) as stipulated in the ASN Law is an ASN employee who occupies a High Leadership Position (JPT). The requirement for civil servants to be appointed to be able to occupy a structural position (Administrator to JPT), one of which must have a predetermined qualification and education level, because essentially the qualifications and level of education will support the implementation of professional duties, especially the application of theoretical frameworks. analysis of methodology for carrying out tasks in his position.

At a practical level, of course, there is an unavoidable controversy because there are parties who see the open selection in structural positions (JPT) causing regeneration in the civil service environment in a certain area does not go well (dpr.go.id in 2013 accessed on January 12, 2018). This is because there is no more order for the state apparatus to queue to get the opportunity to take office. In addition, Ellen Vembrey Rudiyanto et al (2015) quoted Eko Prasodjo as emphasizing the high cost of conducting open selection, as follows:

The selection committee is paid by the state consisting of academics and practitioners based on arrival. Every time he comes with an honorarium of IDR 2,000,000.00 (two million rupiahs) with a meeting of at least 5 (five) times, it will spend 10 million for one person. If there are 5 (five) people, then I will spend 50 million. Then the assessment center stage, which costs depend on the type of question. However, these costs are estimated to be in the range of 7-10 million rupiahs per person.

In addition to this, Article 111 of the ASN Law which states that "... is excluded from government agencies that have implemented a merit system in fostering ASN employees with the approval of the ASN". This will lead to diverse interpretations and create ambivalence when agencies deemed to have implemented a merit system can close themselves and do not want to open positions from other government agencies. Added by Ellen Vembrey Rudiyanto et al (2015), besides being irrelevant with the combination of work performance systems and career coaching, the open selection also becomes irrelevant to the regeneration system. The position auction will disrupt the career system that may have been built and fostered by the state apparatus. Nonetheless, the ASN Law and some of its organic rules have been enacted in the policy package, so that it requires the government and local governments to implement it.

Pekanbaru City Government, Riau Province held the first open selection for Primary High Leadership Position in 2015 while simultaneously holding the mandate of the ASN Law, to fill a number of vacant JPT Primary positions. By referring to Regulation of the Minister of Bureaucracy Reform Number 13 of 2014 concerning Procedures for Filling High Leadership Position Openly in Government Institutions, the Regional Government of Pekanbaru City through the Regional Personnel Agency (BKD) opens open selection registration at 31 (thirty one) JPT and starts moving with the issuance of the Circular Letter of the Mayor of Pekanbaru Number 600 / BKD-PK / 274 concerning JPT Primary Open Selection in the 
Pekanbaru City Government. This is, of course, an opportunity for all civil servants from other regions to participate in the selection. In this policy, one of the considerations is to improve the quality of prospective senior leadership officials through increasingly competitive selection because the number of applicants will remember a lot not only from Pekanbaru but from other regions as well.

In practice, of the 31 (thirty-one) JPTs that were opened for open selection, until on the D-1 before the closing of registration, there were only 19 people who had registered. This was revealed by the Secretary of Pekanbaru City, which was reported by gaungriau.com (http://www.gaungriau.com/indexlainnya/17646/8 accessed on January 12, 2018) that the report received for registering JPT Pratama was still 19 people. So that the number that does not meet the quota, BKD Pekanbaru City as reported by riaurealita.com (http://riaurealita.com/amp/detailberita/1317/contact.php accessed on February 5, 2018) conducts consultations with the State Civil Apparatus Commission (KASN) to get information on filling positions that are quiet and even empty of interested ones. It is said that the Pekanbaru City Government will conduct a re-selection and the possibility of proposing the filling of vacant positions will be filled by enough officials / civil servants who have participated in the selection. This indicates that even though it was held openly, there were several JPT positions that were still empty and less interested.

In addition, the same source, namely gaungriau.com, was acknowledged by the Regional Secretary of Pekanbaru City that until the last H-1 registration, there were no civil servants from other districts/cities registering even though the rules opened opportunities for civil servants outside the Pekanbaru City government. Nevertheless, the guarantee given by the Secretary of the City of Pekanbaru is transparency in the selection process. This is due to the involvement of KASN as the supervisor of the selection process. Contrary to this, the statement of Prof. Sujianto quoted by riauplus.com (http://riauplus.com/politik/9330-asesmen-pejabat-pemko-pekanbaru-diduga-sarat-kkn.html accessed on January 12, 2018) said that "the JPT assessment results will certainly not it was announced that the Pemko Pekanbaru would cause corruption, collusion, and nepotism $(\mathrm{KKN})$. In the system that is applied, the results of the selection will be proposed for three names that are in the top ranking selected and announced by the regional head. However, this was not announced by the Mayor by reason of respecting the feelings of civil servants who did not pass ". This is in line with what was expressed by Herawati (2016) and Setiawan et al (2016) that the emergence of KKN and public protests against the results of open selection is one of them due to the lack of information disclosure for the public to find out who candidates of officials will be appointed or promoted, often times used by certain parties to place entrusted people to occupy positions. Based on the identification of the background of the problem and the identification of the above problems, then the formulation of the problem in this study is 1) How is the Implementation of the Primary Selection Policy for High Leadership in the City of Pekanbaru? 2) What are the obstacles experienced by the Pekanbaru City Government in the Implementation of the Primary High Leadership Open Position Policy? 3) What is the right model for the Pekanbaru City Government in the Implementation of the Open Selection Policy? 


\section{Theory}

\section{Public Policy and Policy Implementation}

The most popular public policy definition has been found by Dye (2002) that public policy "whatever the government chooses to do or not to do". The concept of the policy above implies that the government remains silent on an issue or problem is a public policy on the issue or problem. This definition does not provide a visionary framework of analysis and understanding because this definition does not provide a categorization of government activities. Another understanding was expressed by Lasswell and Kaplan in Awofeso (2011) that policy as a program of achieving goals, values, and directed practices. The policy is a series of actions proposed by a person, group or government in a particular environment by showing obstacles and opportunities for implementing these policy proposals in order to achieve certain goals. The opinions above contain some understanding that public policy is something that is done or not done by the government in order to achieve certain goals by knowing the obstacles. In addition, the above understanding shows that public policy must be realized in the form of programs, legislation or other government actions. Public policy can be referred to as a substantive policy because if the government's actions in dealing with a substantive problem and procedural policies relate to how something will be resolved or who will do it.

Policy implementation is the implementation of activities or programs that are carried out after the making of a policy in the form of regulations. Ripley and Franklin (1982) say that implementation is things that occur after (product) law is issued to certify a program, policy, profit or output that is real/clear. The terminology of implementation refers to a series of activities that follow an official statement about the objectives of the program and the results desired by government officials. Implementation or Implementation is a process to ensure the implementation of a policy and the achievement of the policy. According to Pressman and Wildavsky (1974: 27), explained that "Implementation is interpreted by the various interactions between the preparation of objectives and the means for the purpose of the action in achieving that goal. Or, the ability to connect in a causal relationship between what is desired and the way to achieve it ".

According to Edward III (1980: 28) that "there are 4 (four) factors that influence the success or failure of implementation of the policy, namely communication, resources, disposition, and bureaucratic structure". The illustration of the relationship between these four factors can be seen in the following picture: 


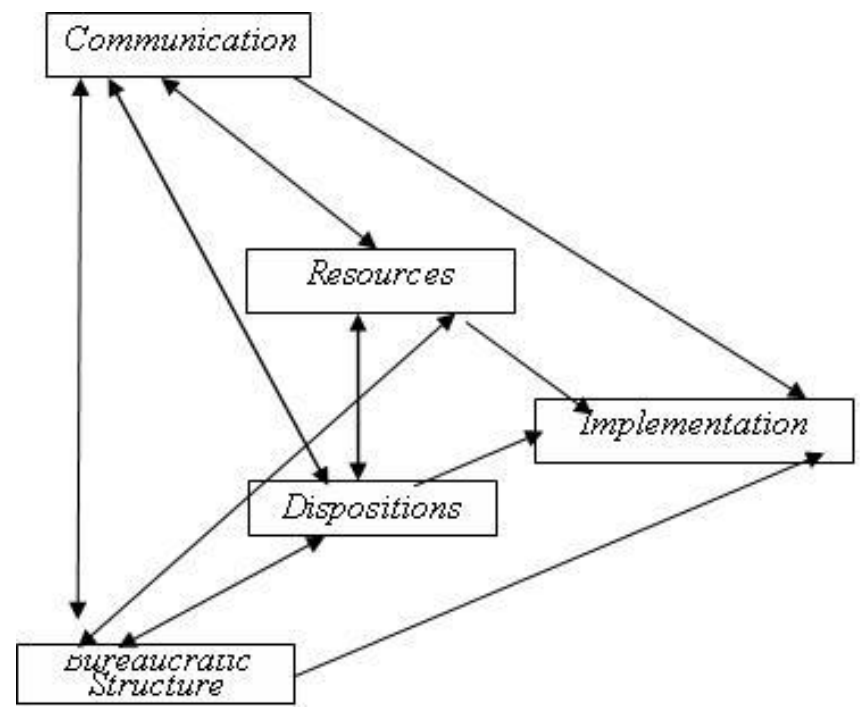

Figure 1. Factors that influence the success of Policy Implementation

Source: Edwards III (1980)

Explanation of the relationship between the four factors for the successful implementation of the policy has been described by Widodo (2010: 96) as follows:

\section{Communication}

Information needs to be conveyed to policy actors so that policy actors can understand what they have to do and what they have to prepare so that policy goals and objectives can be achieved. According to Edward III quoted by Widodo (2010: 97), policy communication has several dimensions, including dimensions of transmission (clarity), clarity (consistency) and consistency (detail) as follows:

(1) The dimensions of transmission require that public policy is delivered not only to the implementers of the policy but also to the policy target groups and other interested parties both directly and indirectly.

(2) The dimensions of clarity (clarity) require that policies that are transmitted to implementers, target groups and other interested parties clearly so that among them know what is the purpose, goals, objectives, and substance of the public policy so that each will know what must be prepared and implemented to make the policy successful and efficient.

(3) Consistency dimensions are needed so that the policies taken are not confusing so that it confuses policy implementers, target groups and interested parties.

\section{Resources}

Resources are an important factor not only in the process of implementing the policy but also as a driver in a government. According to Widodo (2010: 98) citing George C. Edward III classifies resources as follows: 1) Financial resources, budgetary resources, and equipment resources and authority resources; 2) Human resources are one of the variables that influence the success of policy implementation. Edward III in Widodo (2010: 98) states that "probably the most essential resources in implementing policy are staff"; 3) Authority resources where mentioned by Edward III that "Authority is sufficient to make their own decisions that are owned by an institution will affect the institution in implementing a policy. This authority 
becomes important when they are faced with a problem and require to be resolved with a decision ".

\section{Disposition}

Disposition in the literal sense of the organization is defined as the delegation of tasks from the leadership of the organization to subordinates who are considered capable of following up on the task. While in the context of public policy, Widodo quoted Edward III as saying that disposition was "a willingness, desire, and tendency for policymakers to implement the policy seriously so that what became the policy objectives could be realized". Complete information can be seen as follows:

... If the implementation of the policy wants to succeed effectively and efficiently, the implementers not only know what to do and have the ability to carry out the policy, but they also have to have the intention to implement the policy.

While according to Leo Agustino (2006: 159-160) said that the disposition in the implementation of the policy consists of 1) Appointment of bureaucracy, disposition or attitude of the implementers will cause real obstacles to the implementation of policies if existing personnel do not implement policies desired by officials the upper one; 2) Incentives, are one of the techniques suggested to overcome the problem of the attitude of policy implementers by manipulating incentives. Basically, people move based on their own interests, then manipulating incentives by policymakers influences the actions of implementing policies.

\section{Bureaucracy Structure}

Although the sources for implementing policies are sufficient and the implementers (implementors) know what and how to do it, and have the desire to do it, Edward III in Widodo (2010: 106) states that "policy implementation may still be ineffective due to structural inefficiencies bureaucracy". This bureaucratic structure according to Edward III in Widodo (2010: 106) covers aspects such as bureaucratic structure, a division of authority, relations between organizational units and so on.

In connection with this, other public policy experts namely Ripley and Franklin (1978: 44) say that there are 6 (six) characteristics of bureaucracy in running public organizations, namely (1) Bureaucracy was created as an instrument in dealing with public needs (public affair); (2) Bureaucracy is a dominant institution in the implementation of public policies that have different interests in each hierarchy; (3) Bureaucracy has a number of different objectives; (4) The function of the bureaucracy is in a complex and broad environment; (5) The bureaucracy has a high survival instinct, so it is rarely found a dead bureaucracy; and (6) Bureaucracy is not a neutral force and is not in full control of external parties.

Unlike Widodo, although both quote Edward III, Winarno (2010: 150) said that there are 2 (two) main characteristics of the bureaucracy, namely the existence of standard operational procedures (SOP) and the existence of fragmentation. The SOP is an external and internal demand regarding the announcement of the certainty of time, resources and the need for uniformity in carrying out complex and broad organizational tasks. While Winarno (2005: 155) explains that "fragmentation is the spread of responsibility for a policy to several different bodies that require coordination". Edward III in Widodo (2010: 106), states that "Fragmented (fragmented or scattered red) bureaucratic structures can increase the failure of communication because the opportunities for instruction are greatly distorted. The more distorted in the implementation of policy, the more requires intensive coordination ". 


\section{3 .Open Selection}

Selection of HR/employees is a follow-up to employee recruitment. Selection begins after the end of the employee recruitment process. Through employee selection activities, organizations make decisions about who is accepted. The selection process is the special steps used to decide which applicants will be accepted. The process begins when applicants submit applications and end with an admission decision. This is in line with what was conveyed by Berman (2010: 10) "Selection of technically stars when applications have been received".

The selection process is a decision making the process for prospective applicants to be accepted or rejected. Who will be chosen, what process and by whom. Many considerations are needed to choose the right person. The main guideline in holding a selection is the job specification because that's where the quality of human resources is needed. Implementation of selection is one of the important parts in activities or activities of Human Resource Management, especially for the procurement of employees, because with the selection it will produce employees who are in accordance with the needs of the organization both in terms of quantity and quality, which will ensure the smooth running of tasks and activities . Without quality human resources, an organization is in a difficult position to achieve success.

This research focuses on the recruitment and selection process especially for career officials at the level of the Primary High Leadership Position in Pekanbaru City. Recruitment is an important process in producing the quality of an organization's human resources. So that recruitment in Human Resource Management in organizations can determine the existence of an organization. General recruitment means offering to people as a result of new positions, employee needs or expansion of work area. Armstrong (2012: 220) says that recruitment is "... are expressed as ad hoc demands for people because of the creation of new posts, expansion into new activities or areas, or the need for a replacement". Based on the above understanding, it appears that recruitment is carried out at certain times and is carried out due to the need for a job change, expansion of new work areas and the existence of new positions.

If you notice the definition of recruitment and selection above, it applies to employees in general, including officials. In western terminology, career officials in public organizations are executive managers or carrier appointees. In executive managers, positions are usually chosen by the committee that conducts the selection. This is as expressed by Pynes (2009: 207) that "... at the local level and non-profit agencies, the recruitment and selection of executive managers is usually conducted by search committees. The personnel of the council of directors is responsible for the search. Based on the above understanding, officials in public/non-profit organizations are selected and selected by the committee, team and/or selection committee.

The basic objective of the selection process is to obtain employees who are in accordance with the needs of the organization. Selection is a two-way process where the organization offers work positions with appropriate compensation, while prospective applicants evaluate the organization and attractiveness of the position and rewards offered by the organization. But in reality, the selection process is still a one-way process, where the position of applicants can only accept the job position offered by the organization, while the organization has a stronger position to bargain with applicants. However, if there is a shortage of employees, the employee will have more choices in fulfilling the job. Thus, organizations must offer more attractive offers and provide incentives or incentives for applicants.

In the context of the selection and recruitment of Primary High Leadership Position as the 
focus of this research, the stages have been stipulated in the Minister of State Apparatus Empowerment Regulation Number 13 of 2014 concerning the Appointment of High Officials. In these rules, the outline consists of the stages of preparation, implementation, monitoring, and evaluation. The details of the stages of recruitment of High Officials can be seen in figure 2 below:

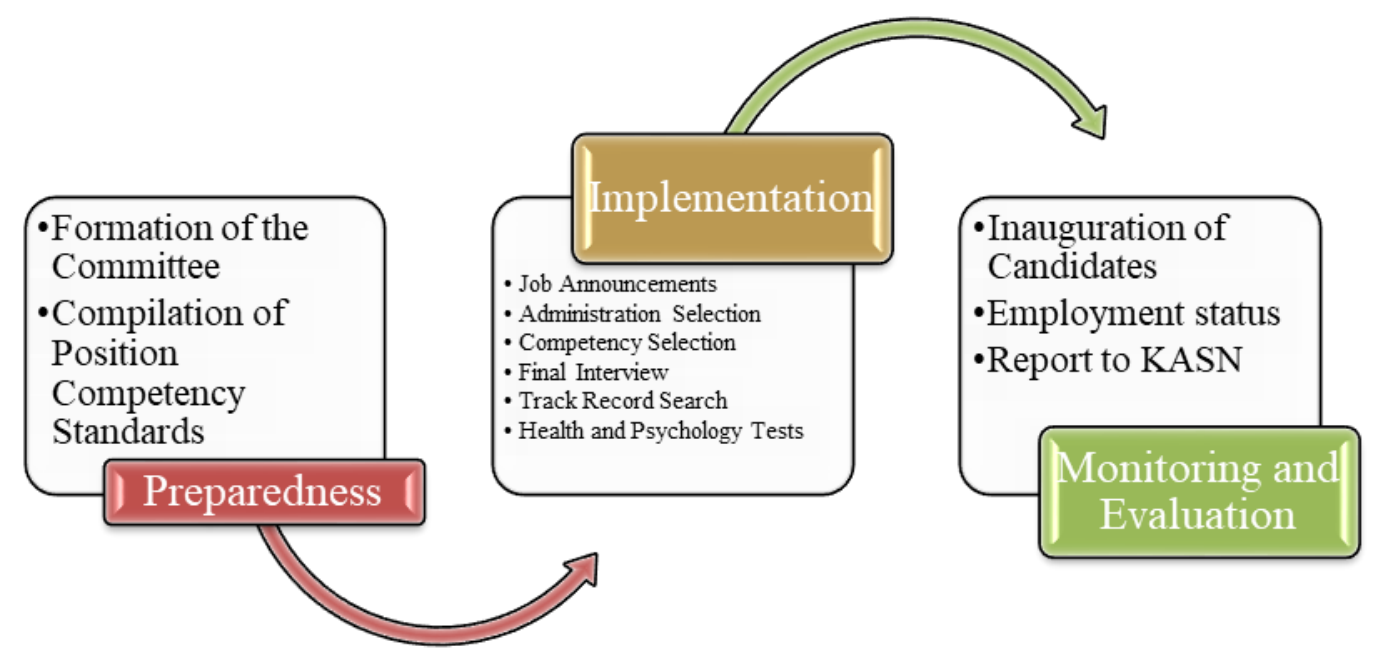

Figure 2. Stages of Recruitment and Selection of High Officials

Source: adapted from Minister of RB Law No. 11 year 2014

This study focuses on open selection, not on the selection of employees with conventional mechanisms. The open selection has various terms such as job tendering and open bidding. Open selection has been practiced in western countries with different terms. Open selection or commonly referred to as JPT filling in an open manner is the process of filling out JPT which is carried out through open/transparent competition with the aim of obtaining apparatus who have the ability, competence, and integrity to fill certain positions effectively and efficiently. In Government Regulation Number 11 of 2017 defining open selection is the announcement of vacancies for JPT filling must be carried out openly through national print media and/or electronic media.

\section{Method}

This research is related to the implementation of the Open Selection of Primary Leadership in the City of Pekanbaru. Therefore, to get comprehensive results, the research design used in this study is a qualitative research design. Creswell (2011: 34) says that "qualitative research is a complex picture, researching words, detailed reports from the views of respondents and conducting studies on natural situations". While the type of research used is descriptive research. This type of research is used because of the nature and purpose of the research that wants to be obtained rather than testing a hypothesis but trying to get a picture of the implementation of JPT Pratama Open Selection in Pekanbaru City.

The technique of withdrawing informants used in this study was conducted in 2 (two) ways, namely using purposive sampling and snowball sampling. The technique of determining informants by purposive sampling is a technique by directly determining informants who are 
considered to master the substance of the study and are considered to have secondary data sources that can be useful for criterion-based selection. While snowball sampling is a technique of determining informants by not determining the number in real terms the informants will get information, but digging data from informants to other informants until the answers are given are considered equal (saturated). The info may in this study can be seen in table 1 below:

Table 1. Research Informant

\begin{tabular}{clc}
\hline No & \multicolumn{1}{c}{ Informant } & $\begin{array}{c}\text { Informant Determination } \\
\text { Technique } \\
\mathbf{1}\end{array}$ \\
\hline 1 & Mayor of Pekanbaru * & \multicolumn{3}{c}{$\mathbf{3}$} \\
2 & Regional Secretary of Pekanbaru City * & Purposive Sampling \\
3 & Assistant II for General Administration in Pekanbaru City & Purposive Sampling \\
4 & Head of the Pekanbaru City Personnel Agency (BKD) * & Purposive Sampling \\
5 & Prof. Dr. Ermaya Suradinata, SH., MH., MS & Purposive Sampling \\
6 & Prof. Dr. Tjahja Supriatna, SU & Purposive Sampling \\
7 & Prof. Dr. Khasan Effendy, M.Pd & Purposive Sampling \\
8 & Participants in Pekanbaru City Open Selection JPT & Purposive Sampling \\
\hline
\end{tabular}

Source: managed by researcher

For the purposes of validating the data obtained, triangulation techniques are carried out. Newman (2013: 186) defines triangulation as "the idea of seeing things from several perspectives that can improve accuracy. Therefore, Newman divides triangulation into 4 (four) types namely size triangulation, observer triangulation, theoretical triangulation, and method triangulation. This research uses 2 (two) types of triangulation namely method triangulation and theory triangulation. This is done because of the several policy implementation theories shown in the previous section, although one main theory is used, theory synthesis will be carried out to support and find uniqueness in this study. In addition, the results of interviews and documentation will be used for data alignment.

\section{Research Results and Discussion}

\section{Implementation of the Primary Open Position Policy for High Leadership in the City of Pekanbaru}

\section{a. Communication Analysis}

Communication is the main requirement for implementing policies (implementers), where policy implementers must know what they have to do, to whom the policy must be channeled so that policies will be implemented can be clear and consistent. Communication in policy implementation according to Edwards III consists of three indicators, namely clarity, transmission, and consistency. In the implementation of the JPT Pratama open selection policy in Pekanbaru City, communication was conducted in 2 (two) directions, namely to civil servants throughout Riau Province and to the selection committee (Pansel). According to 
the City BKPSDM in Pekanbaru, the establishment of the Pansel was carried out by the Regional Head as a Staff Officer and coordinated with KASN. You can see the interview excerpt in full as follows:

... the pansel was formed by the regional head as PPK in the city of Pekanbaru and coordinated to KASN. Incidentally, the Pansel at that time were several professors from IPDN. This is possible considering the appointment conditions of pansel are academics/professionals who have the knowledge and/or experience in accordance with the type, field of duty and vacant position competencies and have general knowledge of competencies and have been consulted to the Commission of State Civil Apparatus.

Regarding the availability of the selection committee, KASN reported in its Annual Report (2018) acknowledged that one of the obstacles in implementing open selection in government was the limited availability of a credible and competent selection committee. While the selection committee has an important role in implementing objective and transparent selection. While at the stage of the selection process, selection announcements were held openly in the form of circulars and electronic media through the official website of the Pekanbaru city government. This was acknowledged by BKPSDM that during the selection process was open. The aspect of transparency is very important. It was further stated that "... since the beginning, BKPSDM has emphasized the transparency aspect in making selection announcements starting from the initial announcement to the stage of determining 3 (three) major candidates for JPT Primary officials". On the other hand, one of the participants from one of the neighboring regions said that the information provided by the City of Pekanbaru was informed 4 (four) days before the selection was open. This becomes odd considering that in the SOP the implementation of the selection made stipulates that the announcement of the selection is at least 15 (fifteen) days before the deadline for receiving the application.

Communication, as expressed at the beginning of this section, is also related to aspects of transparency. The transparency aspect is important considering the JPT Pratama open process in all regions is a sensitive issue. This aspect of transparency is very close to the meaning of clarity that Edwards III (1980: 42) aims at so that policies are transmitted to implementers, target groups and other interested parties so that among them know what is the purpose, goals, objectives, and the substance of the public policy so that each of them will know what must be prepared and implemented to make the policy successful and efficient.

In terms of clarity of purpose, Pekanbaru City Government described that selection is open as a follow-up to the mandate of the State Civil Apparatus Act to produce profiles of JPT Primary officials in areas that are in accordance with the qualifications and competencies needed. Meanwhile according to one academic who was also a member of the selection committee said that "... the selection of JPT Pratama in the ASN Law changed the approach of a closed system to an open system. The closed system used to be very prioritizing the system of seniority and rank and the open system currently prioritizes competency and competition among ASNs. " This is similar to what was expressed by one government expert that "... open selection aims to accelerate regeneration". The results of the Judge's research 
(2016: 542) indicate that policy objectivity is the goals and objectives to be achieved in implementing the policy. The purpose and target of the auction are to really be able to get candidates who have competencies, capacities, and capabilities based on the structural positions carried out.

This quote is intended to speed up filling in vacant positions at the JPT level within government agencies. Also stated by La Folette quoted by Karepesina (2011: 4-5) that "... open selection is intended to produce a merit system in which a mechanism promotes and employs government employees based on their ability to do work, not on their political connections (merit "The system is the process of promoting and hiring government employees based on their ability to perform jobs, rather than on their political connections."). The aim of the JPT open selection has also been explained in Minister of PAN and RB Regulation Number 13 of 2014 concerning Procedures for Filling in JPTs at Government Agencies. It was stated that the purpose of the issuance of this regulation was to carry out the filling of the Main, Intermediate and Primary JPT that was transparent, objective, competitive and accountable. The hope is that the selected JPT is in accordance with the competencies needed for the positions it occupies in accordance with the merit system. On the other hand the recognition from one of the participants who did not qualify for the JPT selection in Pekanbaru City said that open selection conducted in Pekanbaru City tended to be a formality considering the people who were selected and escaped were people who had been predicted to serve in a JPT position before the selection was made.

In fact, as reported by cakaplah.com (accessed on February 4, 2019) the Mayor of Pekanbaru was disappointed with the low value of SAKIP and invited him to put down his position. In detail, it is said that:

... according to what I have said before all officials if the achievement of SAKIP scores is not satisfactory, I invite you to step aside. Give pass that is able to achieve that.

... Determination of the ASN after July. If the SAKIP value is satisfactory, then the person concerned will still sit in the current position. If not, I say, please step aside.

The above quotation shows that the open selection that has been made appears to be not in accordance with the initial objectives set. The performance of JPT Pratama officials who are expected to be in accordance with their competencies turns out not to be as expected. This is in line with the results of the KASN report which concluded that JPT results from open selection were only 8.84 percent with good performance, while there was 48.64 percent with low competence and lack of competency. More can be seen in the following picture: 


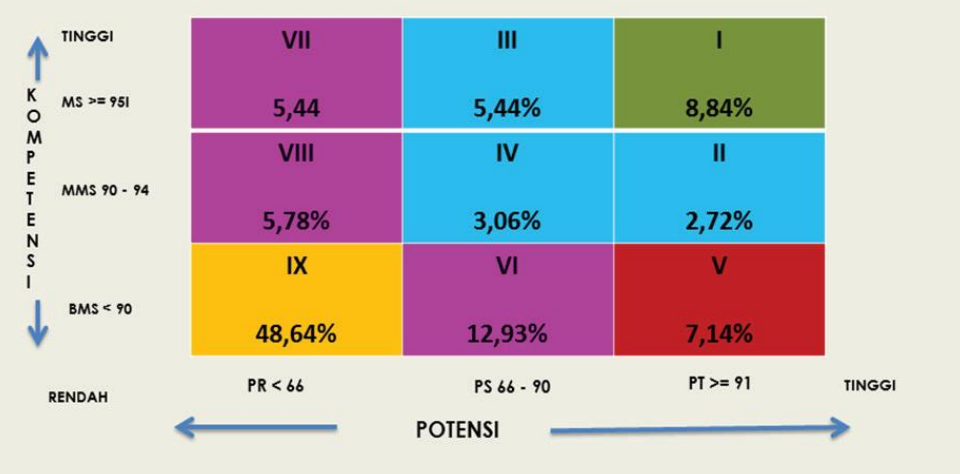

Figure 3. Results of the Primary High School Leadership Assessment Matrix

Source: KASN Performance Report, 2018.

It can be seen in the picture above that pratama high-ranking official who are competent and have the potential to produce optimal performance is only 8.84 percent. While there was 11.22 percent of JPT officials who were actually competent but had low performance. On the other hand, JPT officials with low competence and lack of competency reached 48.64 percent. This is as acknowledged by KASN due to the age structure of Indonesian civil servants, half of whom are over 45 years old.

While the results of research conducted by Susanti (2014) where it was said that the auction of positions carried out in the selection of lurah (head of sub-city) and camat (head of sub-district) in DKI Jakarta had a very positive impact on public services. One of the problems was by the government experts because the committee had the authority to issue 3 (three) names of the best participants to be chosen by the regional head as Officer of Staffing (PPK). This certainly will create potential new transactions between the regional head and the candidate. KASN has published that one of the reasons for the non-neutrality of ASN in the process of regional head elections is the motive for obtaining/maintaining positions. KASN (2018) says that political patronage occurs because the regional head is a political official who is also a PPK who has the authority and power to promote, load, demote ASN employees. The problem of implementing this policy was by van Meter and van Horn (1983: 37) due to social, political and economic environmental conditions in which the political environment, namely the intervention and final decisions of the regional head, became the final decision.

\section{b. Resource Analysis}

Resources in implementing policies, like a machine, are oil, which will not function properly if the oil is lacking/minimal. Resources according to Nugroho (2012: 22) can consist of Human Resources, Financial Resources, Authority Resources, and Infrastructure. While van Meter and van Horn (1983: 22) divides resources into human resources, material resources, and resources methods. The implementation of the JPT Pratama Open Selection Policy in Pekanbaru City is supported by all these resources. This is evidenced by the recognition of BKPSDM that human resources have been prepared to carry out open selection activities. More information can be seen as follows:

... we have prepared a selection committee (pansel) well where the election consists 
of professionals and academics. This year's Pansel 4 (people) as professors of government and public administration were brought in from the Bandung Institute of Domestic Administration (IPDN). While we have provided implementing resources at BKPSDM training in Information and Communication Technology management, especially site management for 2 (two) months in Jakarta. In addition, we for 3 (three) consecutive months asked advocates from the KASN to pay attention to the preparation of this activity. So that this mechanism is expected to have not the slightest violation.

The selection committee in western terminology was revealed by Pynes (2009: 207) as the committee that carried out the selection for non-profit organizations. In full, it was stated that $" . .$. at the local level and non-profit agencies, the recruitment and selection of directors is usually conducted by search committees. The personnel of the council of directors is responsible for the search. The determination of the selection committee was acknowledged by the Pekanbaru City Government in consultation with KASN. This has been regulated by PP No. 11/2017 Article 114 number (4) which reads "informing the selection committee as referred to in paragraph (3), PPK coordinates with KASN". In addition, the open selection committee is required in the same article number (6), namely:

a. Have knowledge and/or experience in accordance with the clear, field of duty, and competence of vacant positions;

b. Have general knowledge about competency assessment;

c. Not being a member/administrator of a political party; and

d. No potential for conflict of interest.

The human resources manager of the JPT open selection process is a general functional in BKPSDM that has been given special training and education by KASN and Kemenpan RB to facilitate the open selection process. Human Resources, in this case, are not only the capacity of the selection committee and secretariat staff but the human resources who register. This is because success and the success of open selection are said to be successful if the results are in accordance with the expected goals, not forced to meet expectations.

As data from the BKPSDM in Pekanbaru City, the number of participants participating in the JPT Pratama open selection in Pekanbaru City was 144 people. The amount is not the real number of people participating in the selection considering that of the 144 people who registered there were 41 people who registered in 2 (two) positions so that a total of 103 real registrants who participated in open JPT selection in Pekanbaru City (number and position can be seen in the attachment to this dissertation ) The quality of the registrant's human resources from the above data cannot be known. This is because there is no data on the qualifications of applicants in the form of education and rank and class of registrants. The data on the number of participants according to education level was 55 people with undergraduate education (S1) and 87 people with a master's level of education and 2 participants with a doctoral level of education. While the number of participants according to rank and class as the data from BKPSDM are 96 people with the rank of Young Trustees (IV / a), 4 young coaches Tk. I (IV / b) and 3 people with the rank of Trustees (IV / c). 
c. Disposition Analysis

Disposition in the implementation of policy by Edwards III is intended as a unity of understanding between implementing policies and directives from leaders (superiors). These limitations can also be caused by ignorance of policy implementers. Disposition according to Edwards III (1980: 32) can be divided into several indicators, namely the appointment of bureaucratic officials and policy incentives. The appointment of the bureaucracy in the implementation of the open selection policy in the city of Pekanbaru turned out to have been realized by the local government where according to the recognition of the head of Pekanbaru City BKPSDM that during the assessment carried out, there was no appointment of bureaucracy amid the assessment. This is intended to avoid the occurrence of misleading of the authority carried out. If the process takes place, while the authorized official is replaced, it will result in disruption of the selection process.

Appointment of bureaucracy, in general, is not an obstacle in the open selection of JPT in the region. However, especially in the JPT Primary selection, the Secretary of the DPRD has additional requirements, namely consultation with faction leaders as stipulated in Law No. 23 of 2014 concerning Regional Governments Article 202 and 205. This, of course, can be a potential violation due to a gap for political intervention. According to the City of Pekanbaru, this is going accordingly and there has been no resistance and protests from the DPRD and selected participants. If this is allowed to happen, then the possibility of resistance in the form of political intervention can occur. To minimize this incident, the gap in political intervention can be anticipated by making consistency in the selection from announcements to the big 3 (three) announcements then coordinating and consulting with the leaders of the DPRD faction.

In addition, incentives in dispositions determine the smooth implementation of open selection policies. The incentives, in this case, are committee fees, team honorariums and the adequacy and feasibility of honorariums and workloads. Jensen and Meckling (1976: 12) in agency theory define incentives as a tool to encourage employees to improve the quality and quantity of their work. The selection committee acknowledged that the incentives in the selection were open as a selection committee in accordance with the workload carried out. In detail, it is said that:

... we as the selection committee which in fact is domiciled in Jakarta feel the incentives provided by the Pekanbaru City Government are very worthed with my workload as academics and professionals. This means that Pekanbaru City government understands and understands that it will respect the achievements and academic status of a professor. Besides that, the trust of the City of Pekanbaru to us as a selection committee became our experience and reputation.

From the Pekanbaru City Government, the Head of BKPSDM in the interview conducted said that incentives, in this case, the selection committee honorarium were given based on budget planning. The incentives that have been set in budget planning are in accordance with the needs of an academic with a professorship degree including accommodation and transportation. In addition, budget allocations are made for BKPSDM staff who are included 
in the open selection secretarial committee. This is done to encourage staff especially staff who have been given ICT management training in Kemenpan RB. So that it does not create an impression on staff that the workload is different but the incentives are the same. This is in accordance with what was revealed by Heneman (1992: 21) on the incentive that "incentives are additional income given to employees not based on job evaluation, but because of differences in job performance".

\section{d. Bureaucratic Structure Analysis}

The bureaucratic structure in the implementation of open selection policies related to the appointment of bureaucracy and selection committees as stipulated in the statutory regulations on their authority is a) Preparing the mechanism for implementing selection; b) Announce information on vacancies in the position of Pratama High Leadership; c) Carry out the selection process including tracking the track record to the place of work; d) Carry out an assessment; e) Announce the results of the selection; f) Recommend candidates for officials who have passed the selection to PPK through authorized officials.

Based on the tasks and functions above, the selection committee as one of the open selection implementing elements knows what must be done. But this does not rule out the possibility of being able to hamper implementation because of the organizational structure that is owned. Standard operating procedures are a major aspect of the success of policy implementation in the dimensions of bureaucratic structures in addition to fragmentation as revealed by Edwards III. The JPT competency standards compiled by the Pekanbaru City Government consist of basic competencies and field competencies. In practice, the Pekanbaru City Government acknowledged that during the open selection process in Pekanbaru City, the position competency standard had not been prepared by the regional government. While ideally, job competency standards must be prepared before an open selection is carried out. Apart from the lack of compilation of job competency standards in Pekanbaru City, Pekanbaru City Government through the Head of BKPSDM said that the position competency standards must be immediately compiled considering that this is closely related to improving performance, not to seek reasons for justification by regional heads. This is in line with what was revealed by the Judge (2016: 541) in his research that the position competency standard is an increase in employee performance as accountability for the appointment and appointment of officials. The occupational competency standard of the State Civil Apparatus or abbreviated as the ASN Competency Standard is a description of the knowledge, skills, and behavior needed by a State Civil Apparatus in carrying out office tasks. Position competency standards, in this case, contain information about: position name, job description, position code, appropriate rank, technical competence, managerial competence, cultural social competence and performance measures.

The second aspect of the bureaucratic structure that we will consider is fragmentation. Edwards III said fragmentation was dispersed from the responsibility for the policy area between several organizational units. Fragmentation according to Nugroho citing Edwards III (2012: 44) is the dissemination of the responsibility of a policy to different bodies so that it requires clear coordination. While on a macro basis, fragmentation in government is defined 
by U. Rosenthal (1986: 1) "... as a government where the processes and processes of government work which involve binding policies and decisions for and in the name of Together life". The more fragmented organizational structure, the more the coordination complex. Sometimes fragmentation is needed if the programs implemented involve many institutions. While fragmentation in terms of van Meter and van Horn (1983: 42) is a relationship between organizations. In detail, it is stated that:

In many policy implementation programs, as a reality of policy programs, good relationships between related institutions are needed, namely communication and coordination support. For this reason, coordination and cooperation between institutions are needed for the success of the program. Communication and coordination are one of the arteries of an organization so that its programs can be realized with their goals and objectives.

In the practice of implementing the JPT open selection policy in Pekanbaru City, there were 3 (three) main institutions that worked, namely BKPSDM, Selection Secretariat and Selection Committee. Each institution has its authority so that fragmentation is formed very little. However, there is a public institution, namely KASN, which has the authority 1) overseeing every stage of the JPT filling process starting from the establishment of agency selection committees, job announcements, implementation of selection, nomination of candidate names, determination, and inauguration; 2) supervise and evaluate the application of principles, basic values, and codes of ethics and codes of conduct for ASN employees; 3) examining documents related to violations of basic norms, codes of ethics and code of conduct of ASN employees, 4) requesting clarification and / or documents required from government agencies to examine reports of violations of basic norms, codes of ethics and code of conduct of ASN employees; and 5) request information from ASN employees and the public regarding reports of violations of basic norms, codes of conduct and codes of conduct of ASN employees.

\section{Barriers to the Pekanbaru City Government in the Implementation of the Primary Selection Policy for the High Leadership Position in the City of Pekanbaru}

\section{a. Time}

The time of implementation as stipulated in the Mayor's Regulation of Pekanbaru is 15 (fifteen) working days for the announcement of open selection. While the selection process is carried out in less than 4 (four) months. Based on the acknowledgment of one participant from another area, there was a lack of clarity on the selection time in which the schedule determined at the beginning of the announcement was not appropriate at the time of implementation. Complete said that "... yesterday one of the things that must be improved is consistency between the time of implementation and the implementation of selection in the field. This is important considering we from outside the city are very determined by the time of implementation. We have to provide at least 3 (three) days if we are going to Pekanbaru to carry out the selection, suddenly the selection is delayed ". While on the other hand, BKPSDM said that:

... the consistency of time for selection implementers is a challenge in itself. This is due to a number of things such as the unpredictable schedule of the Mayor of Pekanbaru and the schedule of the selection committee from outside the city of 
Pekanbaru such as academics from Jakarta who have to adjust their schedules and willingness of the candidates themselves because candidates are regional officials who must adjust to their schedules own.

While the time-related constraints related to the selection announcement where the time limit for prospective JPT selection participants. According to one of the failed administration participants, the time to fulfill administrative requirements was so narrow that most participants, especially those from outside the city of Pekanbaru, failed at the administrative stage. This is in line with what Irfan (2017) stated that "... the time limit for prospective selection participants is sometimes carried out by agencies to limit participants from outside the institution by imposing requirements that are difficult to fulfill by prospective selection participants from outside the agency. There is a tendency for each government agency to want vacancies for positions within its institutions to be filled with insiders ". This is, of course, contrary to the principle of the open carrier system as the open selection process puts forward.

\section{b. Budget}

The budget, in this case, is the implementation cost which is acknowledged by BKPSDM that the budget for the implementation of open JPT selection in Pekanbaru City is the third party that carries out the test or test needed to trace the competency of prospective JPT officials such as the assessment center. In full it is said that:

... other costs, allocated in the context of payment of third parties who carry out the task of tracking the competencies of the participants and the competencies needed, usually in the form of an assessment center. This fee depends on the third party's offer regarding the type of material and the method of selection (assessment). In addition, there are also large costs in selecting medical tests. This happens because participants are not allowed to bring the results of external health tests, so the test is conducted in an integrated manner, namely physical health tests, psych test tests, drug-free tests, and personality tests).

The budget becomes an obstacle in every government activity because the unexpected budget is sometimes bigger than the budget that has been allocated in the budget ceiling. This is a reality given the recognition of the Pekanbaru City BKPSDM towards accommodation and transport from a selection committee of 4 (four) people from Jakarta. It is further said that "unexpected costs that are not budgeted are the costs of accommodation and transportation for the professional academics selection team from Jakarta. This is because initially when budget planning, academics, and professionals were only recruited from universities around Riau. But because there were changes, we experienced a few obstacles ".

\section{c. Bureaucratic Culture}

The Regional Government of Pekanbaru City provides opportunities for employees who meet the qualifications and capabilities to compete in open selection. The absence of discrimination to registrants makes registrants very enthusiastic. If viewed in general, this process will greatly foster a spirit of professionalism, but the bureaucratic behavior in the city of Pekanbaru is still very thick, namely bad taste. This was acknowledged by one of the 
participants in Pekanbaru City that "... I registered to join the selection because I was sure I was able to take part in the selection and my rank was fulfilled. But what was on my mind was a personal judgment in the sense that I was not comfortable registering if my leader did not recommend ".

The interview quotes above show that bureaucratic behavior can hinder the open selection implementation process to increase competitive spirit. Santoso (1992: 21) mentions 2 (two) factors that strengthen work culture, namely the spread of cultural values so that members know the culture contained in the organization; and the level of commitment of members to the organization ". The quote implies that the organizational culture is determined by the understanding of employees of the values that exist in the organization and organization. This is evidenced by Yusrialis (2012: 82-83) that "East culture results in paternalistic interactions between individuals and their superiors, causing problematic situations for employees to innovate and develop careers".

Even though they have the opportunity, prospective candidates can discourage if they do not get a recommendation from their supervisor or do not dare to ask for recommendations from their superiors. This is an invisible and challenging factor in the implementation of open selection policies. Therefore, the function of the leader is to endorse subordinates to develop by recommending subordinates to register themselves as participants in the open selection. This is the same as the results of Nurwana's research (nd: 11) that:

... Constraints faced during the holding of the auction include among them many officials who find it difficult to hone their independent skills when participating in a series of selection stages so that opinions from those who will not participate in the auction program appear and only a few officials follow. Besides that, it was caused by the limited education of ASN (State Civil Apparatus) which was not in accordance with the vacant position offered. This is what causes so far, there are still many ASN (State Civil Apparatus) in certain positions that have not been tested for quality. The leadership spirit possessed by each apparatus is limited so that it also affects the attitude of employees who are not competitive to be able to take part in a series of job selection processes.

The results of the above research are related to the qualifications of the position requirements with the attributes attached to the ASN applying. In addition, bureaucratic culture can hamper the implementation of open selection policies in Pekanbaru City when the selection results are doubted by several parties including applicants (ASN) and the selection committee itself.

\section{Ideal Model for Implementation of Open Selection Policies in Pekanbaru City}

The ideal model for the Implementation of Open Selection Policies in Pekanbaru City departs from the findings of the obstacles faced and the findings of the research as presented in the previous section. One government expert who was also the selection committee recommended that the implementation of policies especially open selection that apply throughout Indonesia not only to local governments but also the central government needed transparency (as a process) in every dimension starting from bureaucratic structures, 
communication, disposition, and resources. As an indicator, Edwards III has not set transparency indicators specifically on the communication dimension in the case of JPT Primary open selection. This is as expressed by one expert that communication including announcements should be transparent. In detail, it was said that "... communication in the open selection of JPT Pratama in Pekanbaru City especially the transmission indicators, clarity, and consistency must be done transparently starting from the announcement stage of the selection process to the announcement of the selection results". By Rakhmawanto (2016: 416) emphasizes 2 (two) basic principles in the appointment of ASN positions by applying the merit system, namely:

... First, there is transparency; This was done as an effort to fulfill the demands of reform, namely the principle of openness in the selection mechanism starting from the delivery of information on vacant positions, registration, conducting tests, announcements, inauguration and taking oaths, to their placement. This principle can be assessed by employees in the work environment and society in general so that they can provide a more objective and rational assessment. Second, there is accountability; this is done considering job selection will be related to the interests of the wider community.

In addition, to avoid any political interests in the form of compromises and transactions, Irfan (2017) said that tightening and setting the duration of the selection stages were determined. Regulations concerning the management of the State Civil Apparatus in which Civil Service Development Officer (PPK) article 53 of Law Number 5 the Year 2014 are 1) Minister in the Ministry; 2) Leadership of Institutions in Non-Ministry Government Institutions; 3) Secretary General at the Secretariat of State Institutions and Non Structural Institutions; 4) Governor in the Province; 5) Regents/mayors in the Regency / City. At the local government level, the regional secretaries (Sekda) are more eligible to become PPKs because the Regional Secretary is the highest career officer in the area who has experience and pioneered careers from staff. Thus the ideal model for the Implementation of the JPT Open Selection Policy in Pekanbaru City is an enrichment of the Edwards III Implementation model which can be seen in the following figure: 


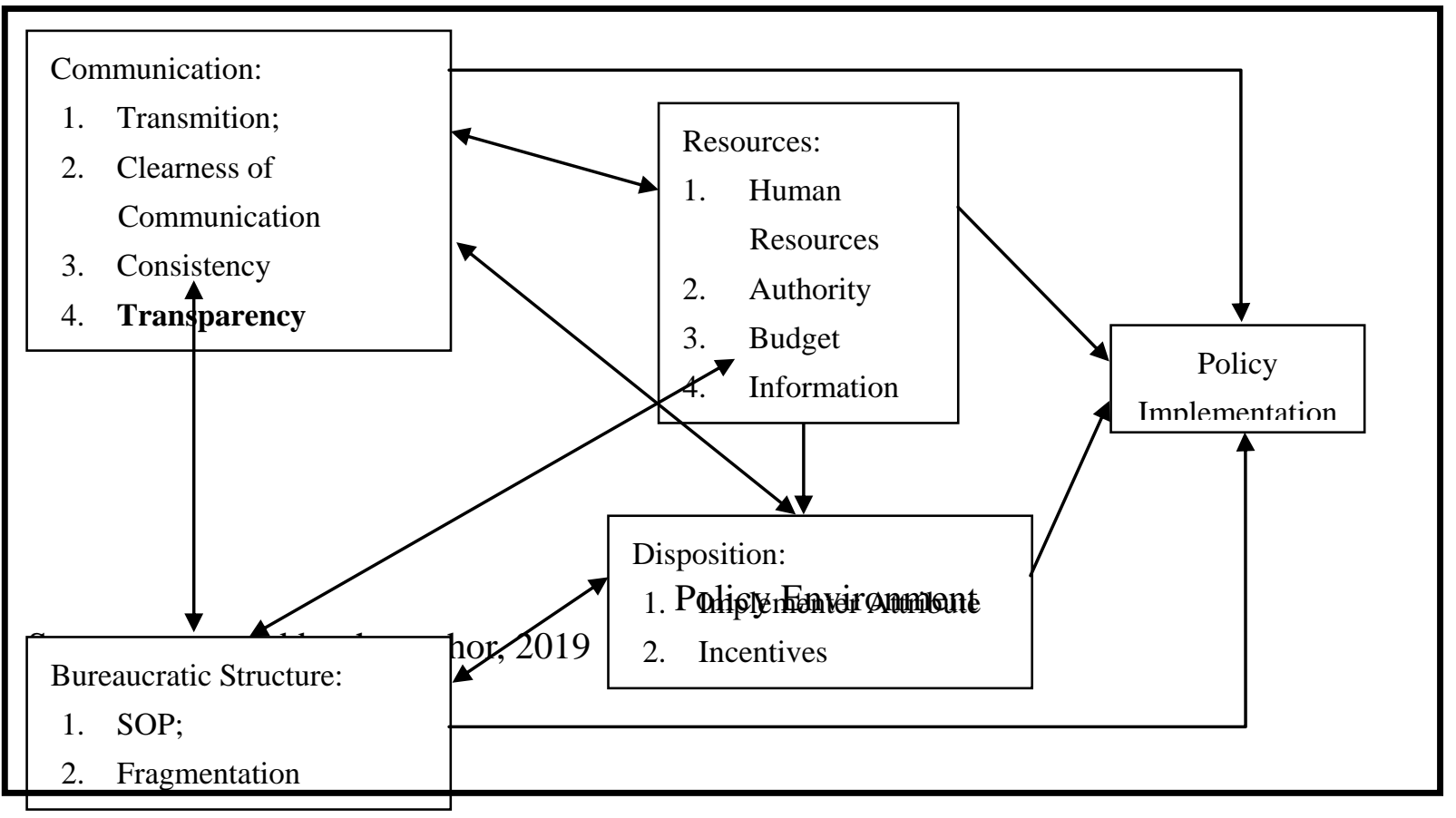

Figure 4. Ideal Model for Implementing JPT Open Selection Policies in Pekanbaru City

The implementation of the Open Selection Policy in the Primary High Leadership Position in Pekanbaru City can be seen from several aspects, namely a) Communication Aspects which include communication between the selection committee and BKPSDM, communication between the selection committee and PPK, Communication between BKPSDM and tenuous participants open selection and announcement of results; 2) Resource Aspects where the use of budgetary resources is mostly intended to finance the assessment center. While human resources in the selection process strongly support both HR in the selection committee and HR at BKPSDM; 3) Disposition aspect is seen from the smoothness of the selection process due to the absence of official appointments while the selection process takes place and there is a match between the incentives with the workload that is owned by the selection committee and secretariat; and 4) Bureaucratic structure, it appears that existing SOPs have resulted in unclear time when implementing selection. But on the other hand, there is clarity of authority, main tasks, and functions between open selection implementation organizations, namely the selection committee, BKPSDM, and the secretariat.

In order to avoid miscommunication between participants and implementers, it is best to be efficient when implementing the selection phase by opening vacancies for 6 (months) positions before certain positions will be vacated. The success of Pekanbaru City Government in providing human resources and infrastructure needs support in the form of providing other resources, namely the budget for maintenance of facilities and infrastructure.

\section{Reference}

Agustino, L. (2008). Dasar-dasar Kebijakan Publik. Bandung: Alfabeta. Amin Widjaja Tunggal, 2007. Audit Manajemen. Jakarta : Rineka Cipta. 
Armstrong, M. (2012). Armstrong's handbook of Human Resources. London: KoganPage.

Awofeso, O. (2011). Democracy and Democratic Practice in Nigeria: Issues, Challenges and Prospect.

Berman, E. M. (2010). Human Resources management in Public Service: Paradoxes, Process and Problems. Sage Publication. Inc.

Creswell, J. W. (2012). Research Design: Pendekatan Kualitatif, Kuantitatif dan Mixed. Yogyakarta. Pustakan Pelajar.

Dye, T. R. (2013). Understanding Public Policy, $13^{\text {th }}$ Edition. Pearson Education Inc: New York.

Edward, III, G. C. (1980). Implementing Public Policy. Congressional Quarterly Press: Washington.

Heneman, R. L. (1992). Addison-Wesley Series on managing Human Resources. Merit Pay: Linking Pay Increase to Performance Ratings. US. Addison-Wesley Longman.

Herawati, N. R. (2016). Evaluasi Lelang Jabatan Camat dan Lurah Pemerintah Provinsi DKI Jakarta. Jurnal Ilmiah Ilmu Pemerintahan, 2(2). Maret 2016.

http://riauplus.com/politik/9330-asesmen-pejabat-pemko-pekanbaru-diduga-sarat-kkn.html http://riaurealita.com/amp/detailberita/1317/contact.php

Irfan, M. (2017). Seleksi Terbuka jabatan Pimpinan Tinggi di Lingkungan Instansi Pemerintah. Policy Brief. Badan Kepegawaian Negara.

Jensen, M. C., dan William, H. M. (1976). Theory of the Firm: Managerial Behavior, Agency Costs and Ownership Structure. Harvard Business School. https://doi.org/10.1016/0304-405X(76)90026-X

Karepesina, M. T. (2011). Merit Sistem dalam Penempatan Pegawai pada Dinas Pendidikan dan Kebudayaan Kabupaten Buru. Masters thesis, Universitas Hasanuddin.

Newman, W. L. (2013). Metodologi Penelitian Sosial: Pendekatan Kualitatif dan Kuantitatif Edisi 7. Jakarta. Indeks.

Nugroho, R. (2011). Public Policy. Elex Media Computindo: Indonesia.

Nurwana, M. A. (2014). Evaluasi Lelang Jabatan di Lingkungan Pemerintah Provinsi Jawa Tengah Tahun 2013-2014. Disertasi Universitas Diponegoro.

Pynes, J. E. (2012). Human Resources Management. USA: Wiley.

Rakhmawanto, A. (2016). Model Pengangkatan Jabatan Pimpinan Tinggi Aparatur Sipil Negara dalam Perspektif UU Nomor 5 Tahun 2014. Jurnal Penelitian Hukum Dejure. Volume 16 Nomor 4, Desember 2016.

Ripley, R. B., \& Franklin, G. A. (1982). Bureaucracy and Policy Implementation. Dorsey 
Press: Homewood.

Rosenthal, D. M. (1986). Two concepts of consciousness. Philosophical Studies, 49(May), 329-59. https://doi.org/10.1007/BF00355521

Rudiyanto, E. V. dkk. (2015). Orientasi Proyek Reformasi Birokrasi. Universitas Tarumanegara.

Sepriyanto, D. S. dkk. (2013). Pelaksanaan Pengakatan Pejabat Struktural Kelurahan di Lingkungan Kota Singkawang. Jurnal Universitas Tanjungpura 2013.

Setiawan, O. dkk. (2016). Pelaksanaan Seleksi Terbuka Pejabat Pimpinan Tinggi Pratama di Lingkungan Pemerintah Kota Bandar Lampung. Jurnal Hukum, 4(2), November 2016. Universitas Lampung.

Susanti, D. A. (2014). Kebijakan Lelang Jabatan Pengangkatan Camat dan Lurah di DKI Jakarta Tahun 2013 dalam rangka Good Governance. Disertasi Universitas Islam Negeri Syarif Hidayatullah. 2014.

Van Meter, D. S., \& Van Horn, C. E. (1975). The Policy Implementation Process : A Conceptual Framework. Administration \& Society, 6(4), 445-488. https://doi.org/10.1177/009539977500600404

Widodo, J. (2010). Analisis Kebijakan Publik. Malang: Bayumedia.

Wildavsky, A. 1974. The Politics of the Budgetary Process, $2^{\text {nd }}$ Edition. Boston: Little Brown \& Co.

Winarno, B. (2007). Kebijakan Publik, teori dan Proses, Jakarta: Media Pressindo.

Yusrialis. (2012). Budaya Birokrasi Pemerintahan (Keperihatinan dan Harapan). Jurnal Sosial Budaya. Volume 6 Nomor 1, Januari-Juli 2012.

\section{Copyright Disclaimer}

Copyright for this article is retained by the author(s), with first publication rights granted to the journal.

This is an open-access article distributed under the terms and conditions of the Creative Commons Attribution license (http://creativecommons.org/licenses/by/4.0/). 